\title{
半導体リソグラフィ技術の進展とEUVリソグラフィの開発状況
}

\author{
岡崎信次 \\ 技術研究組合 極端紫外線露光システム技術開発機構（†210-0007 神奈川県川崎市川崎区駅前本町11-1 パシフィックマークス川崎11階）
}

\section{Evolution of Lithography and Development Status of EUV Lithography}

\author{
Shinji OKAZAKI \\ Extreme Ultraviolet Lithography System Development Association, \\ 11th Floor, Pacific Marks Kawasaki, 11-1 Ekimae-honcho, Kawasaki-ku, Kawasaki, Kanagawa 210-0007
}

(Received June 17, 2010)

\begin{abstract}
The development of ULSI devices are promoted by the development of lithography. In the development of lithography, optical lithography played an important role. Higher numerical aperture (NA) optics, shorter exposure wavelength light and various resolution enhancement technologies are introduced to obtain higher resolution. However, optical lithography is now facing the resolution limit. To overcome this situation, various ideas in optical lithography have been investigating. Adopting extremely shorter exposure wavelength, that is the use of Extreme Ultraviolet (EUV) light, is another choice. Various research institute and universities in the world are intensively investigating EUV lithography. In this paper the evolution of optical lithography is introduced first. Then current status and future prospects of EUV lithography are discussed.
\end{abstract}

Key Words: Optical lithography, Resolution enhancement technology, EUV lithography

1.はじめに

半導体集積回路の高性能化・高集積化によって, 我々 の生活は大きく様変わりした。昔, 一部の限られた研究 者しか使えなかったような高性能の計算機, いやそれを 数段上回る性能の計算機が, いまや我々の机の上のノー トパソコンとして, 誰でも使えるようになった。 またそ れは，単独の計算機としての機能に止まらず，ネット ワークを介して，世界中とつながっている，さらに携帯 電話をはじめとするモバイル型の携帯機器は, 世界中の どこに居ても自分のオフィスと同様の便利さを提供でき るようになっている。 こういった高速で, 高性能な機能 は, 殆どが半導体集積回路の高性能化, 高集積化によっ てもたらされたものであろう。

この高性能化・高集積化を支えてきた中心技術が，半 導体微細加工技術である. 特に半導体基板上に微細なパ ターンを創り出す, 半導体リソグラフィ技術の進化が, それを牽引したといっても過言ではない. 中でも光リソ グラフィ技術の果たしてきた役割は大きい ${ }^{1)}$.

この微細化のトレンドをFig. 1に示す. 集積回路の開 発が始まった当初は密着型露光技術が主流で, 解像度も 数 $\mu \mathrm{m} レ$ ベルであった. 本格的な高解像度化は, 縮小投 影型の露光技術の登場で始まった，後に詳述するが，高
解像度化はまず露光光学系の改良という形で進み, さら に露光波長の短波長化がこれに続いた。またマスクの改 良や露光装置の照明系の改良等, いわゆる解像度向上技

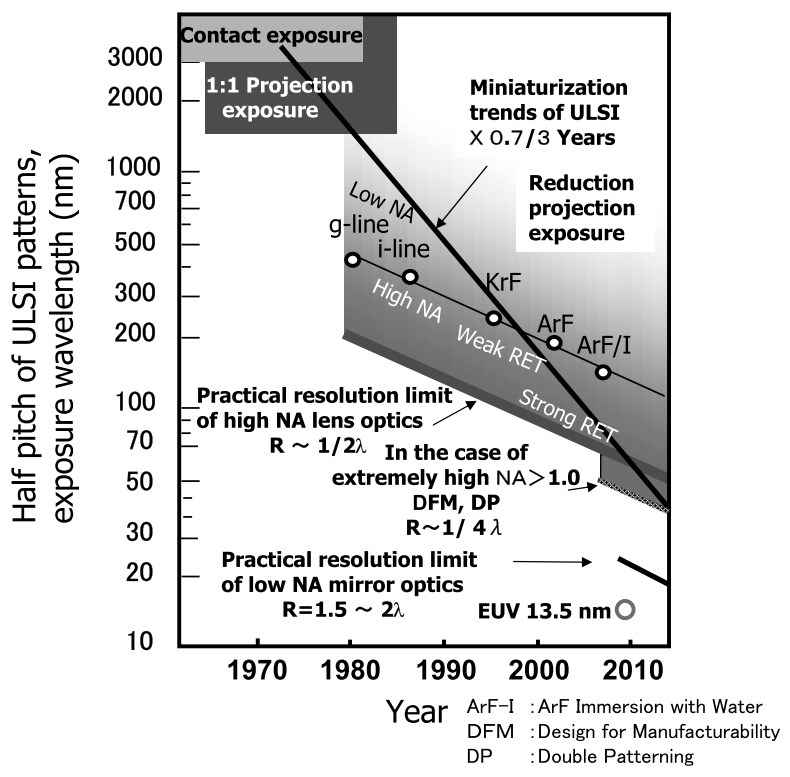

Fig. 1 Miniaturization trend of ULSI devices and exposure wavelength reduction trend. 
術の導入によって, 解像度の向上が進んだ。さらに最近 では, 光学系の開口数を, 空気中露光では限界であった 1.0 を超える純水を用いた液浸露光技術が採用され，露 光波長の 3 分の 1 程度の加工も実現されるようになってい る.

これらの技術の開発の経緯を紹介すると共に，今後さ らなる高解像度化を狙ったダブルパターニング技術, さ らに次世代の技術として期待されている様々なリソグラ フィ技術を紹介したい. 特に次世代技術の本命として注 目されているEUV露光技術について，レーザー技術の 応用である光源技術との関係を中心に, その可能性と課 題について議論したい.

\section{2. 半導体リソグラフィ技術の発展}

\section{1 光リソグラフイ技術の開発経緯}

Fig. 1で示したように, 光リソグラフィ技術は, 密着 露光技術，等倍投影露光技術を経て，縮小投影露光技術 によって，その継続的な高解像度化が始まった。投影露 光技術における解像度Rは, 次のレーリーの式で与えら れる2).

$$
R=k_{1} \lambda / N A
$$

ここで，入は露光波長，NAは投影光学系の開口数， $k_{1}$ は, レジスト材料や露光方式により決まる比例定数であ る。

最初に縮小投影露光技術が導入された当時の露光波長 は, 高圧水銀灯の輝線である $\mathrm{g}$ 線 $(436 \mathrm{~nm})$ であった。当 時, 要求される最小加工寸法は, 縞状のパターンのピッ チの半分の值として $2 \mu \mathrm{m}$ ないし $1.3 \mu \mathrm{m}$ 程度と, 露光波長 に比べ，十分に大きい值であった。このため，投影光学 系の開口数も, NA:0.28程度と, 比較的小さなものが使 われた。

リソグラフイ技術における解像度は，一般に縞状のパ ターンのピッチの半分, すなわちハーフピッチ $(h p)$ で表 される。以降, 解像度をこのハーフピッチの值で表記す る.

その後, 要求される最小加工寸法の微細化と共に，ま ず開口数の向上が露光装置メーカーによって進められ た. しかし, 当時の半導体デバイスの構造は, 表面の段 差が大きく, 深い焦点深度が要求された。 このため, 高 NA化と共に，短波長化も模索された。最初に試みられ たのは，遠紫外光(Deep UV光)である KrFエキシマレー ザー光 $(248 \mathrm{~nm})$ の導入であったが，レジスト材料の開 発が間に合わず，やはり水銀灯の輝線であるi線 (365 nm) がg線に続いて, hp $0.8 \mu \mathrm{m}$ 時代, $h p 0.5 \mu \mathrm{m}$ 時代 に実用化された ${ }^{3)}$.

しかし, 半導体集積回路の高集積化は続き, さらなる 微細化が要求された。 $\mathrm{KrF}$ 用のレジスト材料の開発進展 と共に, $h p 0.25 \mu \mathrm{m}$ 時代にエキシマレーザー露光技術が 実用化された4)。しかし， $\mathrm{KrF}$ の波長は248 nmであり， 要求される最小加工寸法と露光波長が同じ時代となっ た。
これとほぼ同じ時期に，短波長化以外に解像度を向上 させる, いわゆる解像度向上技術が盛んに検討され

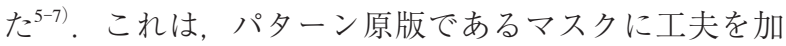
える方式や，光源形状を変形することによって， $k_{1}$ 值を 小さくする技術である。この結果 $k_{1}$ 值は 0.8 程度であった ものが 0.5 以下にできるようになった。しかし， $k_{1}$ 值を小 さくするといっても，1回の露光での原理的な $k_{1}$ 值の限 界は0.25である。孤立したパターンを微細にする方法 は，様々存在する。例えば，パターンを形成後，オー バーエッチングすることで，パターンを細らせることが できる。しかし，パターンのピッチを微細化することは できない。このため, リソグラフィ技術の解像度の高さ を示す尺度は, パターンのピッチかその半分のハーフ ピッチとなる。一般には, このハーフピッチ $(h p)$ が解像 度の尺度となる。

また, ウエハの上面を平坦化する化学機械研磨技術 (CMP技術)の導入によって，半導体デバイスの段差が 小さくなり，焦点深度の制限が緩和され，短波長化たけ でなく高NA化への展望も開けたことも特記すべき事柄 である。

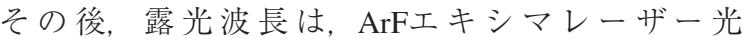
$(193 \mathrm{~nm})$ となったが, 要求される最小加工寸法は $h p 130 \mathrm{~nm}-h p 90 \mathrm{~nm}$ と, 露光波長に比べてはるかに小 さい。このため，次に紹介する様々な解像度向上技術の 採用が進んだ。

\section{2 解像度向上技術}

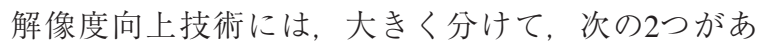
る。マスクを透過する光の位相を制御する位相シフト法 と, 照明光源の形状を制御する変形照明法である.

Fig. 2に従来の露光法(通常照明) と, 位相シフト法, 変 形照明法を比較する。位相シフト法はFig. 2 (c) に示す ように, マスクの隣り合った開口部の位相を 180 度反転 させることで，隣り合った開口部の干渉を抑制する方法 である。この方法には，開口部パターンの周辺の遮光部 分から位相を反転させた光を一部透過させるハーフトー ン型や，遮光部分を設けず，すべて位相を反転させた透 過パターンで構成するクロムレス型などのバリエーショ
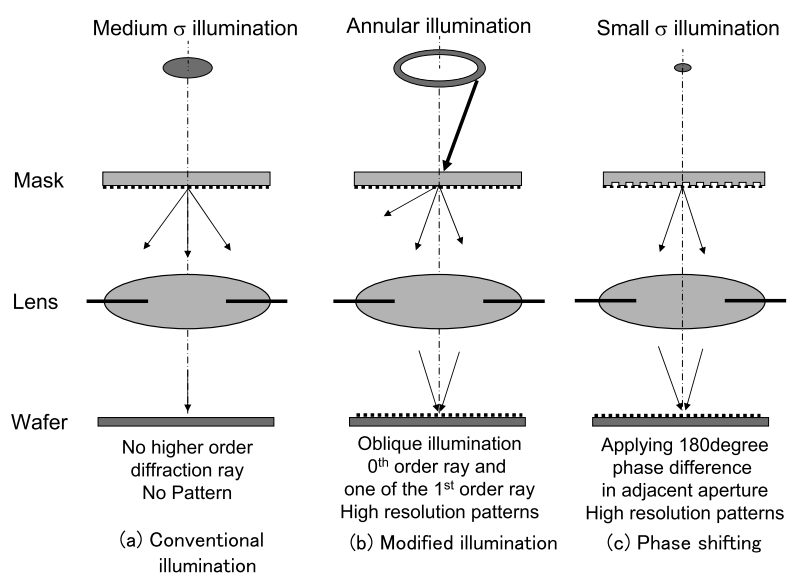

Fig. 2 Principles of resolution enhancement technology. 
ンがある.

一方, 変形照明法は, Fig. 2 (b) に示すように回折光 の一部を使うことで, 通常照明では透過しない大きな回 折角の光を取り込むことが可能となり, 解像度を向上す ることが可能となる.

しかし，これらの解像度向上技術では，隣り合うパ ターン同士の配列や，回折光の方向をそろえるため, 設 計上の制約も多いという問題がある。このため，パター ンの形成が容易になるように，設計側が歩み寄る，いわ ゆるDFM(Design for Manufacturability)が必要な状況であ $ろ^{8)}$.

\section{3 液浸露光技術とSMO技術}

$\mathrm{ArF}$ 露光技術に続いて, さらなる短波長化として $\mathrm{F}_{2}$ レーザー光 $(157 \mathrm{~nm})$ を用いる技術が，一時盛んに検討 されたが，レジスト材料等の光透過率向上に課題が多い ため, 断念された。 これに変わる技術として, 最終レン ズとウエハの間に，屈折率の大きな液体を介在させるこ とで，1を超えるNAを実現しようという動きが盛んに なった ${ }^{9-12)}$ ，実用的には液体として水が用いられ，NAも 1.35 程度の投影レンズが実用化されている.

Fig. 3にこの液浸露光技術の原理を示す. 最終レンズ とレジストの間が空気の場合，全反射してしまうよう な，大きな角度で入射する光も，水が介在することで， レンズとの屈折率の差が小さくなり，透過することが可 能となる. この結果, 大きなNAの光学系を作ることが 可能となり, $h p 65 \mathrm{~nm} h \mathrm{hp} 45 \mathrm{~nm}$ レベルのパターンの加 工も，解像度向上技術を併用することで可能となった。

しかし，先にも述べたように，解像度向上技術は，パ ターン設計上の制約があり，複雑な形状のパターンへの 適用は難しい. そこで, 計算機シミュレーションを駆使 してマスク形状や光源形状を最適化してしまおうという 動きが, 最近盛んに行われている ${ }^{13-15)}$ 。これは, 計算機 リソグラフィ技術と呼ばれる動きである。特にSMO (Source Mask Optimization) 技術では, マスクに様々な補 助パターンを付けたり, 光源形状を複雑に制御すること で，設計パターンへの忠実性を高くできる，こういった 動きは, 本質的な解像度の向上技術ではないものの, 設 計形状の制限が緩和され, 実効的に半世代程度の解像度 向上が得られる。

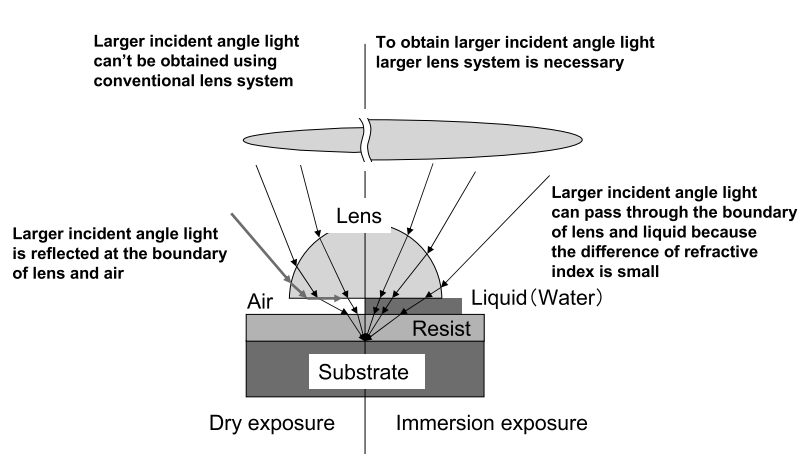

Fig. 3 The principle of immersion lithography.

\section{4 ダブルパターニング技術}

本質的な解像度向上には，先にも述べた $k_{1}$ 值の $0.25 を$ 打破する必要がある。これを実現する方法としては, 露 光を複数回に分けることで実現できる ${ }^{16,17)}$. 様々な方法 が提案されているが, Fig. 4にその基本的な原理を示 す. Fig. 4 (a)に示すのは, 露光とエッチングをそれぞ れ2回繰り返す,リソエッチリソエッチ型と呼ばれるダ ブルパターニング法である。まず1回目の露光で, 限界 に近いピッチでパターンを露光し，これを何らかの方法 で寸法を細らせて，パターンを下地膜に転写し，その 後，レジストを塗布して，ピッチを半分ずらせて，再び 露光することで，倍ピッチのパターンが得られる．原理 的にはこれを繰り返すことで，さらに細かいパターンの 形成も不可能ではない. 但し, 2回目以降のパターン形 成は，1回目のパターンに重ね合わせる必要があるため, 重ね合わせ精度が悪いと, 寸法精度が悪くなってしまう という課題があり, 露光装置の重ね合わせ精度の飛躍的 な向上が必要である。

この課題を解決する手法として, 縞状のパターン形成 というものにほぼ限定されるものの, 重ね合わせ精度に 依存しない, ダブルパターニング法が提案されてい る ${ }^{18)}$. Fig. 4 (b) にその手法を示す。ここでは, 通常のダ ブルパターニング手法と同様に, 寸法を細らせた縞状の パターンをまず形成する。ここでパターンの寸法は, ピッチの3分の1とする。次いでこれにスペーサ膜を形成 する。ここで膜厚をパターンピッチの3分の1とする. 次 いで, パターン全体をエッチングして，最初に形成した パターンの側壁部分にのみ形成した膜が残るようにす る。その後, 最初に形成したパターンを除去すると, 当 初の2倍のピッチのパターンが形成できる。この場合, 露光装置の重ね合わせ精度は，パターンの寸法には影響 されないというメリットがある。平面的には，最初に形 成したパターンの周囲に全て側壁が残るので, これを除 去するための2回目の露光が必要となり，これもダブル パターニングということになる。実際この技術は，すで に一部のフラッシュメモリーの製造に実用化されてい る.

これらのダブルパターニングに共通する課題は, 露光 回数が2回になるだけでなく，新たな多くのプロセス工 程が必要であり，コストが大幅に高くなり工程が長くな

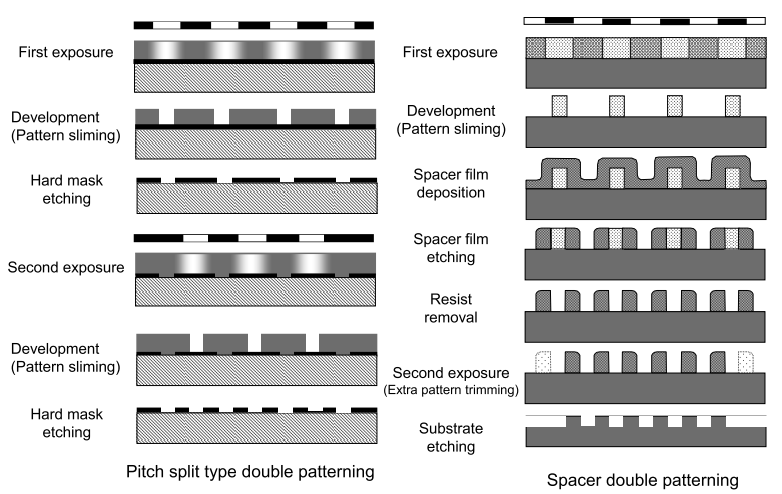

Fig. 4 Double patterning. 
るということである ${ }^{19}$.

\section{EUVリソグラフィ技術への期待}

\subsection{EUVリソグラフィ技術の概要}

露光波長の短波長化という意味で, $13.5 \mathrm{~nm}$ という極 端紫外光 (Extreme Ultra-violet)を用いるEUVリソグラ フィ技術は，解像度向上技術やダブルパターニングと いった，パターン形状への制限や，複雑な工程が不要と なるという利点がある20-22)。一方，EUV光というX線領 域の光を用いるため, 光源や光学系だけでなく, 露光シ ステム，マスク，レジスト材料等にまったく新しい技術 を開発する必要がある。 Fig. 5にその課題を示す，最大 の課題は, $13.5 \mathrm{~nm}$ の波長を効率的に発生させる光源の 開発と, 波長 $13.5 \mathrm{~nm}$ の光を効率的に反射する多層膜光 学系の開発である. $13.5 \mathrm{~nm}$ の光を効率的に透過する材 料はないため, マスクも多層膜を用いた反射型となる.

\subsection{EUV光源の開発}

EUV光は, XeやSnのプラズマから発生する光を用い ることが提案されている，プラズマの発生方式で，レー ザー励起型 (LPP: Laser Produced Plasma) と放電励起型 (DPP: Discharge Produced Plasma)に分けられる ${ }^{23-24)}$. 前 者は，YAGレーザーやCO $\mathrm{CO}_{2}$ レーザーをターゲット物質で ある，XeやSnに照射して得られるプラズマから発生す る光を利用する。一方後者は，XeやSnの蒸気中で放電 により得られるプラズマから発生する光を利用する。こ れらの方式の, 開発経緯をFig. 6に示す.

LPPでは，当初YAGレーザー光をXeに照射する方式が 用いられてきた ${ }^{25-27)}$. Xeの密度を高めることにより変換 効率が高められることから, ターゲットとして, Xeの クラスタジェットや，液体Xe，固体Xeがターゲットと して検討されたが，変換効率は $1 \%$ 程度と低かった。こ れに対し，Snをターゲットとして $\mathrm{CO}_{2}$ レーザーを用いる ことで，変換効率を $2 \%$ 以上に高められるという理論的 な検討結果や実験結果が報告された ${ }^{28-30)}$ 。この結果, 最 近ではSnのドロップレットに $\mathrm{CO}_{2}$ レーザーを照射する方

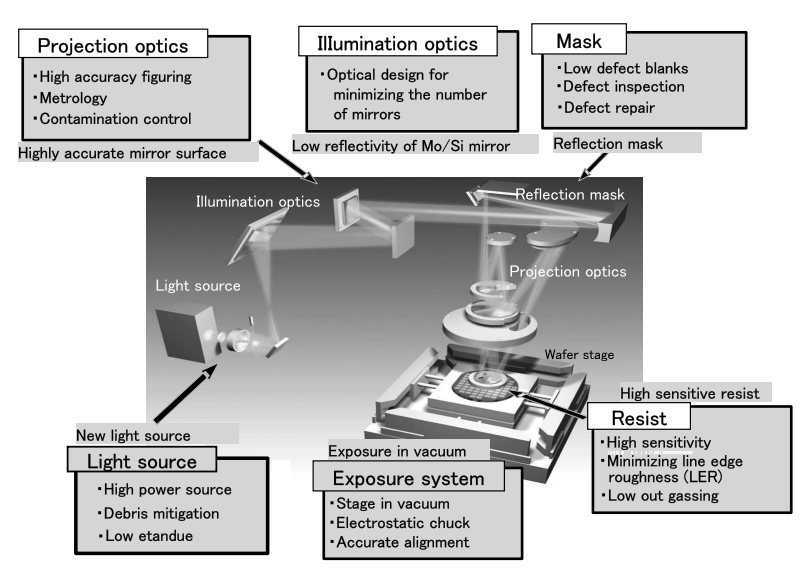

Fig. 5 Issues of EUV lithography.

\section{Laser produced plasma(LPP)}

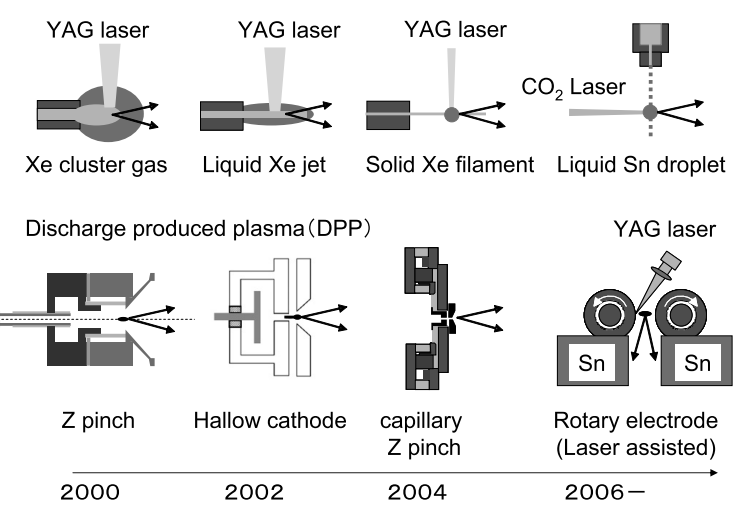

Fig. 6 Evolution of EUV light source.

式の開発が進められている31,32).

DPPでは，Xeガス中で様々なピンチプラズマの形成方 式が検討された ${ }^{33-35)}$ 。さらにXeガスをSn蒸気にすること で，変換効率の向上が図られた。しかし，DPPに扔ける 最大の課題は，電極の放熱にあり，これが出力の上限を 支配していた，放熱を効率よく行う方式として，回転電 極方式が提案された 飛躍的に向上している，さらにレーザー照射で放電の卜 リガーとするLA-DPP (Laser Assisted-DPP) 方式が検討さ れている ${ }^{38)}$.

実用的な露光装置で要求されるパワーは，少なくとも 100-200 Wであり, 量産用としてはさらに大きな出力 が要求されている。現状ではLPP, DPP両方式共に, ピークパワーとして100 W程度が報告されているが，平 均出力ではまだ数十Wである。 今後, 平均出力を $100 \mathrm{~W}$ から $200 \mathrm{~W}$ とすることが, 当面の課題であろう.

\section{3 その他のEUVリソグラフィ技術の開発状況 ${ }^{39-42)}$}

光源以外のEUVリソグラフィ技術の課題としては, 光学系，マスク，レジストがある，特に光学系は，照明 光学系と投影光学系から成り立ち, どちらも多層膜反射 鏡から構成される。多層膜反射鏡としては，Mo/Siの多 層膜が用いられ，その最大の反射率は70\%程度であ る. 従って反射鏡を2枚使っただけで光強度は半分に なってしまう，均一で広い面積を照明する照明光学系で 6枚程度, 高精度で高解像な投影像を得るために少なく とも6枚の反射鏡が必要となる。ささらにマスクも多層膜 反射マスクを使うため，13回程度多層膜反射が必要とな る.この結果, 光源から出た光は, 100 分の1程度しかウ エハに到達しない.

現在研究開発に用いられているフルフィールド露光装 置では，NA:0.25であり，6枚系の光学系が用いられてい る. 従来の $\mathrm{ArF}$ 露光用光学系が30枚程度のレンズ，すな わち60面程度の光学面が使われているが，10分の1の枚 数でより高い解像度を得るため, 1 枚の反射面により多 くの機能を持たせる必要があり, 超高精度な非球面光学 系が用いられている39).

マスクの最重要課題は, ブランクス(吸収体パターン 
形成前の多層膜が形成された状態のマスク基板）におけ る位相欠陥の検出にある。基板上の異物や傷の上に多層 膜が形成されたり，多層膜形成中に異物が取り込まれた りした場合，完成した多層膜の表面はほぼ平滑化されて しまうことが多いため, 多層膜の上からは通常の光では 欠陥を検出できない。このため, こういった欠陥の検出 には露光波長での欠陷検出が必要となる40)

レジスト材料としては, 高感度, 高解像度, 低LWR (Line Width Roughness)を同時に実現することにある。 材料としては化学増幅型レジストが用いられ, 最新の データとして20 nm程度の解像度, $15 \mathrm{~mJ} / \mathrm{cm}^{2}$, LWR: $5 \mathrm{~nm}$ 程度が得られている。化学増幅系材料では, 酸の 拡散距離の制御や反応基の均一性の向上が今後の課題で ある ${ }^{41-43)}$.

露光装置の開発は, 現在ASML社が, 実用機の開発を 提示しており，2010年秋にも6台のプレ量産機のデバイ スメーカー等への納入を発表している ${ }^{44)}$. さらに高NA 化し, スループットを向上した(すなわち光源の出力を 大きくした)装置の開発を明言している。一方ニコンは, 当面 $A r F$ 液浸露光とダブルパターニング技術の進展で対 応するとのこと．EUVリソグラフィ技術の採用はその 先との考えで, $h p 16 \mathrm{~nm}$ 以降への導入を考慮して, 光学 系の高NA化を進めている ${ }^{45)}$.

\section{4. まとめ}

リソグラフィ技術は, 半導体集積回路の高集積化の原 動力として発展してきた. 特に光リソグラフィ技術の進 展は非常に顕著であり, 現在もリソグラフィ技術の主流 である。しかし, 解像度の限界も近く, 解像限界を突破 するため, DFMと呼ばれる設計側からの歩みよりや， マスクから光源まで最適化するSMO技術が重要となっ てきている。ささらに本質的な高解像度化を実現するた め, ダブルパターニング技術なども採用され始めている が，コスト的な課題も大きい。 この状況を突破する技術 としてEUVリソグラフィ技術が期待されている。しか し, 従来技術と大きく異なるX線領域の光を用いるた め, 開発課題も多い. 特にレーザー技術を駆使した大出 力光源技術の開発が, その実用化の鍵を握っていると いっても良い。

\section{謝 辞}

本研究の一部は，新エネルギー・産業技術総合開発機 構(NEDO)の研究プロジェクトとして行われたものであ る.

\section{参考文献}

1) S. Okazaki: J. Vac. Sci. Technol. B 8 (1991) p.2829.

2) 例えば久保田宏著：光学, 岩波書店 (1964).

3）長谷川昇雄, 柳沢寛, 黑崎利栄, 橋本哲一：電子通信学 会論文誌 J66-C (1983) p1084

4) V. Pol, J. Bennewitz, G. C. Escher, M. Feldman, V. A. Firtion, T. E.
Jewell, B.E. Willcomb, and J. T. Clemens: Proc. SPIE 633 (1986) p.6.

5) M. D. Levenson, N. S. Viswanathan, and R. A. Simpson: IEEE ED-29 (1982) p.1828.

6）渋谷真人：透過照明用被投影原版 特公昭 62-50811.

7) 堀内敏行, 鈴木 雅則：第32回応物学会講演予稿集 2 (1985) 294

8) L. Liebman, Z. Baum, I. Graur, and D. Samuels: Proc. SPIE 6925 (2008) p.69250C.

9) W. W. Tabarelli and E. Lobach: European Patent 0023231 (1979).

10) 高梨明絃, 原田達男, 明山正元, 近藤弥太郎, 黒崎 利栄：特願昭 56-37977 (1981).

11) S. Owa and H. Nagasaka: Proc. SPIE 5040 (2003) p.724.

12) B. Streefkerk, J. Baselmans, W. G. Ansem, J. Mulkens, C. Hoogendam, M. Hoogendorp, D. G. Flagello, H. Sewell, P. Graupner: Proc. SPIE 5377 (2004) p.285.

13) A. E. Rosenbluth, D. O. Melville, K. Tian, S. Bagheri, J. T-Azpiroz, K. Lai, A. Waechter, T. Inoue, L. Ladanyi, F. Barahona, K. Scheinberg, M. Ssakamoto, H. Muta, E. Gallagher, T. Faure, M. Hibbs, A. Tritchkov, and Y. Granik: Proc. SPIE 7274 (2009) p.727409.

14) A. Poonawala, W. Stanton, and C. Sawh: Proc. SPIE 7640 (2010) p.76401M

15) J. Zimmermann, P. Gräupner, J. T. Neumann, D. Hellweg, D. Jürgens, M. Patra, C. Hennerkes, M. Maul, B. Geh, A. Engelen, O. Noordman, M. Mulder, S. Park, and J. De Vocht: Proc. SPIE 7640 (2010) p.764005.

16) S. D. Hsu, W. P. Corcoran, M. Eurlings, W. T. Knose, T. L. Laidig, K. W. Nampler, S. Roy, X. Shi, C. M. Hsu, J. F. Chen, J. Findors, R. J. Socha, and M. V. Dusa: Proc. SPIE 4691 (2002) p.476.

17) C-M. Lim, S-M. Kim, Y-S. Hwang, J-S. Choi, K-D. Ban, S-Y. Cho, J-K. Jung, E-K. Kang, H-Y. Lim, H-S. Kim, and S-C. Moon: Proc. SPIE 6154 (2006) p.615410-1.

18) W-Y. Jung, C-D. Kim, J-D. Eom, S-Y. Cho, S-M. Jeon, J-H. Kim, J-I. Moon, B-S. Lee, and S. K. Park: Proc. SPIE 6156 (2006) p.61561J-1.

19) G. Hughes, L. C. Litt, A. Wuest, and S. Palalyanur: Proc. SPIE 7028 (2008) p. 70281P.

20）木下博雄，金子 隆司，武井弘次，竹内 信行，石原 直：第 47回応物学会講演予稿集 2(1986) 322.

21) H. Kinoshita, K. Kurihara, Y. Ishii, and Y. Torii: J. Vac. Sci. Technol. B 7 (1989) 1648.

22) J. E. Bjorkholm, J. Boker, L. Eichner, R. R. Freeman, J. Gregus, T. E. Jewell, W. M. Mansfield, A. A. MacDowell, E. nL. Raab, W. T. Silfvast, L. H. Szeto, D. M. Tennant, W. K. Waskiewicz, D. L. White, D. L. Windt, O. R. Wood II, and J. H. Bruning: J. Vac. Sci. Technol. B 8 (1990) 1509.

23) H. Fiedorowicz, A. Bartnik, Z. Patron, and P. Parys: Appl. Phys. Lett. 62 (1993) 2778.

24) U. Stamm et al: $3^{\text {rd }}$ International Workshop on EUV Lithography (2001).

25) G. D. Kubiak, L. J. Barnerdez, K. Krenz, and W. C. Swertt: Proc. SPIE 3676 (1999) p.669.

26) H. Fiedorowicz, A. Bartnik, H. Daido, I. W. Choi, M. Suzuki, and S. Yamnagami: Opt. Commun. 184 (2000) 161.

27) B. A. M. Hanssen, M. Berglund, O. Hamberg, and H. M. Hertz: J. Appl. Phys. 95 (2004) 4432.

28) H. Tanaka, A. Matsumoto, K. Akinaga, A. Takahashi, and T. Okada: Appl. Phys. Lett. 87 (2005) 041503.

29) K. Nishihara, A. Sasaki, A. Sunahara, and T. Nishikawa: EUV Sources for Lithography, V. Bakshi Ed. (SPIE Bellingham 2005) Chap. 11.

30）西村 博明他：プラズマ・核融合学会誌 80 (2004) 325.

31) D. C. Brandt, I. V. Fomenkov, A. I. Ershov, W. N. Partlo, D. W. Myers, R. L. Sandstrom, N. R. Böwering, G. O. Vaschenko, O. V. Khodykin, A. N. Bykanov, et al.: Proc. SPIE 7636 (2010) p.763611.

32) H. Mizoguchi, T. Abe, Y. Watanabe, T. Ishihara, T. Ohta, T. Hori, A. Kurosu, H. Komori, K. Kakizaki, A. Sumitani, et al.: Proc. SPIE 7636 (2010) p.763608.

33) V. Fomenkov, R. M. Ness, J. R. Oliver, S. T. Melnvchuk, O. V. Khodvkin, N. R. Bowering, C. L. Rettig, and J. R. Hoffman: Proc. SPIE 5037 (2003) p.807. 
34) Y. Teramoto et al: Symp. on Pulsed Power and plasma application (2003) p82-87.

35) J. Pankert, K. Bergmann, J. Klein, W. Neff, O. Rosier, S. Seiwert, C. Smith, S. Probst, D. Vandrevange, G. Siemons, et al.: Proc. SPIE 5374 (2004) p.152.

36) V. M. Borizov, et al.: Russian Patent Application 2002120301 (2002).

37) J. Pankert, R. Apetz, K. Bergmann, M. Damen, G. Derra, O. Franken, M. Janssen, J. Jonkers, J. Klein, H. Kraus, et al.: Proc. SPIE 6151 (2006) p.61510Q.

38) M. Yoshioka, Y. Teramoto, P. Zink, G. Schriever, G. Niimi, and M. Corthout: Proc. SPIE 7636 (2010) p.763610.

39) M. Lowisch, P. Kuerz, H-J. Mann, O. Natt, and B. Thuering: Proc. SPIE 7636 (2010) p.763603.
40) T. Terasawa, T. Yamane, T. Tanaka, O. Suga, T. Kamo, and I. Mori: Proc. SPIE 7636 (2010) p.763602.

41) S. Tarutani, H. Tsubaki, H. Takahashi, T. Itou, K. Matsunaga, G. Shiraishi, and T. Itani: Proc. SPIE 7639 (2010) p.76391N.

42) T. H. Fedynyshyn, R. B. Goodman, A. Cabral, C. Tarrio, and T. B. Lucatorto: Proc. SPIE 7639 (2010) p.76390A.

43) R. Gronheid, A. V. Pret, B. Rathsack, J. Hooge, S. Scheer, K Nafus, H.Shite, and J. Kitano: Proc. SPIE 7639 (2010) p.76390M.

44) C. Wagner, N. Harned, P. Kuerz, M. Lowisch, H. Meiling, D. Ockwell, R. Peeters, K. van I.-Schenau, E. van Setten, J. Stoeldraijer, et al.: Proc. SPIE 7636 (2010) p.76361H.

45) T. Miura, K. Murakami, H. Kawai, Y. Kohama, K. Morita, K. Hada, and Y. Ohkubo: Proc. SPIE 7636 (2010) p.76361G.
縮小投影型露光 (reduction projection exposure)

原版となるマスク (レチクルとも呼ばれる)を実際の回 路寸法の数倍 (一般的には4倍)の大きさで作成し，これ を, 縮小投影光学系を用いて, 半導体等の基板上に投影 する方法を縮小投影型露光と呼ぶ. この時, マスクと基 板を静止させ，マスク全体の回路図形を一度に投影露光 し, 露光後に基板を載せたステージを一定距離 (一般的 には回路の大きさで規定される距離)移動し, 再び露光 を行う方式の露光装置をステッパと呼ぶ.これに対し て, マスク基板と半導体基板を, 相対的に縮小比に応じ
た速度でスリット状の露光領域を同期走査しながら露光 し，走査が終わったら，再び反転走査して露光する，同 期走査方式の露光装置をスキャナと呼ぶ. 前者に比べ, 後者は同じ露光領域を露光する場合, 投影光学系が小さ くできることや，焦点合わせや重ね合わせにおける自由 度が高いため, 高精度化しやすい等の理由から, 最先端 の露光装置としては, 後者が用いられることが多い.

(岡崎 信次) 